\title{
The Four Pillars of Emperors and Generals in Chinese History
}

\author{
Raymond Lo \\ University of Hong Kong
}

\begin{abstract}
The Four Pillars of Destiny is a traditional Chinese destiny analysis system based on a person's birth data, year, month, day, and hour. When expressing this birth information into the Chinese calendar, one can see details about the person's life and achievement deduced from the interaction of the 5 basic elements. The birth elements of famous emperors and generals in Chinese history have been interesting area of study and some of these famous people's birth data are very unique that can offer deeper insight in the research and study of Four Pillars of Destiny. This article focuses on the most fascinating examples of Chinese historical figures and explains how their special life path and achievement can be clearly reflected by their respective Four Pillars of Destiny.

Keywords: Four Pillars of Destiny, Tzu Ping, Cheung Fai, Romance of Three Kingdoms, Kwan Kung, Wu Zetian, Tang Tai Zong, Yang Gui Fei, Song Tai Zu, Yue Fei, Yang Edge
\end{abstract}

China has more than 6,000 years of fascinating history of dynasties with many famous Emperors and Generals. These great outstanding people in history made their marks and contributions in the long river of cultural and political development in China. The fortune, fate and destiny of these famous people, as reflected in their respective birth data, has been an important reference in the study of Four Pillars of Destiny. Some of the birth data of the Emperors are so unique and outstanding that they are classified as special category of Four Pillars. In this article, I will give various examples of these famous Emperors and Generals and briefly explain the special quality of their Four Pillars which is one determining factor contributed to their successes in history.

The modern way of analyzing Four Pillars—-the "Tzu Ping” way, is said to be invented by Tzu Ping who lived in around 1000 AD. However, in classical books, there are records of Four Pillars of ancient people as far back as the time of about Three Kingdoms (200 AD). In my collection, I have the Four Pillars of a famous general Cheung Fai, who lived from 183 to 238 AD. And his Four Pillars is the most unique with nothing but only pure water elements.

Cheung Fai 183 AD

Hour Day Month Year

癸 癸 癸 癸

Water Water Water Water

亥亥亥 亥

Water Water Water Water

丁戊已庚辛壬

Fire Earth Earth Metal Metal Water

Raymond Lo, Grand Master, Bachelor of Social Sciences, University of Hong Kong, China; main research fields: Chinese Metaphysics, Feng Shui, Four Pillars of Destiny, and I Ching Divination. 
$\begin{array}{cccccc}\text { 巳 } & \text { 午 } & \text { 未 } & \text { 申 } & \text { 西 戊 } \\ \text { Fire } & \text { Fire } & \text { Earth } & \text { Metal } & \text { Metal } & \text { Earth }\end{array}$

This is very unusual Four Pillars as he was born in water pig year, water pig month, water pig day, and water pig hour. We have no means to check the accuracy of this birth data. However, it very much matches with the description of this person in the famous novel The Romance of Three Kingdoms. In the book, Cheung Fai was described as short, sturdy, and black color face. In the five elements system, water goes downward, fire and wood go upward. Hence, it is true that water people are shorter, and fire and wood people are taller. Also water is black color and round shape; this totally matches with the outlook of Cheung Fai. Also he is clever but alcoholic, this is also consistent with the quality of massive amount of water in his destiny. If the Four Pillars is only dominated by the self element, it is considered "Extremely strong."

The analogy is like a very fast car running on a highway; it is impossible to stop, so it is not recommended to put a road block as the car will crash. So it is better to let it go its way and avoid any obstructions against him. So his favorable elements are resources (metal), Friends (water), and intelligence (wood). Any obstructions by Power (earth) and money (fire) will be bad luck.

Even the accuracy of this Four Pillars is doubtful, this hypothesis totally matches with his history. His golden time must be the 20 years when he is in his 20s and 30s during the 20 years of metal luck pillar. When he came to luck of yin earth goat, he was declining and he died in the luck of yang earth horse, and in $238 \mathrm{AD}$ the year of yang earth horse, he was murdered by his soldiers when sleeping.

The unique Four Pillars of Cheung Fai is always a good reference to explain the "extremely strong" category of destiny in the study of Four Pillars.

A second very interesting Four Pillars belongs to another famous general during the time of "Three Kingdoms.” He is Kwan Kung, a comrade and foster brother of Cheung Fai, serving the Kingdom of Shu.

Here is his Four Pillars.

Kwan Kung 178 AD

Hour Day Month Year

戊戍戊戊

Earth Earth Earth Earth

午午午午

Fire Fire Fire Fire

乙甲癸壬辛庚已

Wood Wood Water Water Metal Metal Earth

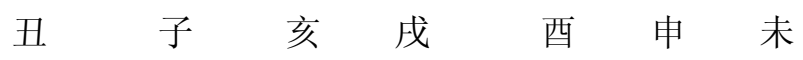

Earth Water Water Earth Metal Metal Earth

This is another very special Four Pillars with yang earth horse year, yang earth horse month, yang earth horse day, and yang earth horse hour. Yang earth is strongest in the horse month of June. Hence, such Four pillars are classified as "Yang Edge.” A yang Day Master born in the strongest month. Yang Edge people are mostly military commanders as they get their strength from the support of colleagues and friends, like a General in command of thousands of soldiers. For such Yang Edge people, the dangerous time will be when the Yang Edge came under clash, as such clash will stir up his unfavorable enemies who will rise up against him.

This Four Pillars with four times yang earth horse also matches well with the description of Kwan Kung in the novel Romance of Three Kingdoms. He is tall, strong, handsome guy with red face. These outlooks very 
much fit in with the strong fire and earth elements in his chart. He is well respected for his loyal and faithful character, and earth is element of faith. Even his horse is called "Red Rabbit" and this matches with his four fire horses elements.

A very interesting episode in Chinese history is the prosperous Tang dynasty (618-705 AD). There are quite a few famous Kings and the most interesting is the first and only Empress in Chinese history Wu Zetian (624-705 AD) and she ruled China as Empress from $690 \mathrm{AD}$ until her death in $705 \mathrm{AD}$.

Wu Zetian is a fascinating woman who first served the father King Tang Tai Zong as concubine then married to the son King Tang Gao Zong as Queen. As Gao Zong was weak in health, she was in control and dominated major decisions until her husband King died at $683 \mathrm{AD}$, then she took over as Empress and ruled China from 690 to 705 AD. Her Four Pillars is very colorful, with Red Charm, plenty of aggressive intelligence (Killing the boss), and "month Star of Virtue."

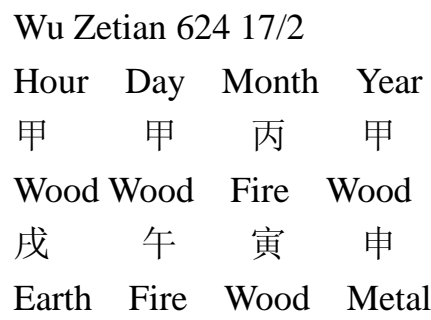

$\begin{array}{lllllllll}76 & 66 & 56 & 46 & 36 & 26 & 16 & 6 & \\ \text { 戊 } & 己 & \text { 庚 } & \text { 辛 } & \text { 壬 } & \text { 癸 } & \text { 甲 } & \text { 乙 } & \\ \text { Earth } & \text { Earth } & \text { Metal } & \text { Metal } & \text { Water } & \text { Water } & \text { Wood } & \text { Wood } \\ \text { 午 } & \text { 未 } & \text { 申 } & \text { 西 } & \text { 戊 } & \text { 亥 } & \text { 子 } & \text { 丑 } \\ \text { Fire } & \text { Earth } & \text { Metal } & \text { Metal } & \text { Earth } & \text { Water } & \text { Water } & \text { Earth }\end{array}$

She is strong yang wood born in spring season; yang wood is compared to a tree, strong character not easy to compromise and quite stubborn. This reflects her tough character to fight all oppositions. There are 3 yang woods showing up in her chart; these are her enemies and competitors. Indeed, she faces very strong competition as she is just one outstanding concubine among thousands of beautiful women in the palace to compete for the affection of the King. She shows very strong yang fire which is her aggressive intelligence, killing boss quality, and this yang fire is her "Month star of virtue" contributing to her charm. The fire is also supported by a combination of Tiger, Horse, Dog making massive amount of fire on her Earthly Branch. And the Horse is her "Red Charm." The power element—metal, is under clash and totally suppressed by her strong fire. Hence, she totally dominates and controls her men.

It is interesting to also see the Four Pillars of her two husbands-Emperor Taizong and Emperor Gao Zong.

Tang Tai Zong 599 23/1

Hour Day Month Year

癸戊乙戊

Water Earth Wood Earth

丑午丑午

Earth Fire Earth Fire 


$\begin{array}{lccrrrr}59 & 49 & 39 & 29 & 19 & 9 & \\ \text { 辛 } & \text { 庚 } & \text { 己 } & \text { 戊 } & \text { 丁 } & \text { 丙 } & \\ \text { Metal } & \text { Metal } & \text { Earth } & \text { Earth } & \text { Fire } & \text { Fire } \\ \text { 未 } & \text { 午 } & \text { 巳 } & \text { 辰 } & \text { 卯 } & \text { 寅 } \\ \text { Earth } & \text { Fire } & \text { Fire } & \text { Earth } & \text { Wood } & \text { Wood }\end{array}$

Tang Gao Zong 628 19/7

$\begin{array}{lccc}\text { Hour } & \text { Day } & \text { Month } & \text { Year } \\ \text { 乙 } & \text { 戊 } & \text { 己 } & \text { 戊 } \\ \text { Wood } & \text { Earth } & \text { Earth } & \text { Earth } \\ \text { 卯 } & \text { 子 } & \text { 未 } & \text { 子 } \\ \text { Wood } & \text { Water } & \text { Earth } & \text { Water }\end{array}$

$\begin{array}{llllll}56 & 46 & 36 & 26 & 16 & 6 \\ \text { 乙 } & \text { 甲 } & \text { 癸 } & \text { 壬 } & \text { 辛 } & \text { 庚 }\end{array}$

Wood Wood Water Water Metal Metal

丑子亥戌西电

Earth Water Water Earth Metal Metal

Both Emperors are weak Yang Earth day masters who need the support of strong fire, which they can find in Wu Zetian's chart. These explain why they are both so much attracted by the same woman. Especially the son Emperor Gao Zong is very weak yang earth, totally lacking fire support. His luck also does not provide him with any fire, instead, there are plenty of water and wood, exhausting and attacking his earth. Hence, he suffers from head ache and very weak health. This is caused by weak fire with weak blood circulation and digestion system. The very strong water in his day pillar-House of spouse, reflects a powerful wife. His luck pillars between 36 and 56 are also strong water, making his wife very powerful. And the water supports his hour of wood and attacks his earth. Hence, it is very clear that his wife Wu Zetian totally dominates and controls him. This Four Pillars amazingly matches with history.

In Tang Dynasty, there is also another famous romantic love story about one of the famous beauty-Yang Gui Fei and the Emperor Xuan Zong. It is a sad story as the Emperor was accused of too indulged in love with the woman, and eventually his soldiers forced him to order the death of his lover Yang Gui Fei.

The following are the Four Pillars of the sad couple.

Yang Gui Fei 719 22/6

Hour Day Month Year

乙戈庚已

Wood Earth Metal Earth

卯午午末

Wood Fire Fire Earth

\begin{tabular}{lllll}
46 & 36 & 26 & 16 & 6 \\
\hline & & 癸 &
\end{tabular}

Wood Wood Water Water Metal 
$\begin{array}{ccccc}\text { 亥 } & \text { 戊 } & \text { 西 } & \text { 申 } & \text { 未 } \\ \text { Water } & \text { Earth } & \text { Metal } & \text { Metal } & \text { Earth }\end{array}$

Emperor Xuan Zong 685 8/9

Hour Day Month Year

癸戊 乙 乙

Water Earth Wood Wood

丑寅西西

Earth Wood Metal Metal

$\begin{array}{lllllll}70 & 60 & 50 & 40 & 30 & 20 & 10\end{array}$

成已庚辛壬癸甲

Earth Earth Metal Metal Water Water Wood

寅卯辰已午末 未

Wood Wood Earth Fire Fire Earth Metal

The amazing observation is that Xuan Zong is also weak yang earth requiring the support of fire and earth, like Emperor Tai zong and Gao Zong before him, hence, he is very much in love with Yang Gui Fei, a very strong yang earth girl with strong fire and earth elements. And Yang Gui Fei died in 756 AD, which is year of fire Monkey directly clashes against Xuan Zong's day pillar of yang earth Tiger. The Tiger is his House of spouse, and such clash kills his wife.

Moving on to Song Dynasty—-960-1279, the interesting set of Four Pillars belongs to the first Emperor Tai $\mathrm{Zu}$ of Song. The following is his Four Pillars.

Song Tai Zu 927 21/3

Hour Day Month Year

庚 丁 甲 丁

Metal Fire Wood Fire

戌卯辰亥

Earth Wood Earth Water

$\begin{array}{llllll}55 & 45 & 35 & 25 & 15 & 5\end{array}$

戊已庚辛壬癸

Earth Earth Metal Metal Water Water

戌亥子丑寅卯

Earth Water Water Earth Wood Wood

He is a military general supported by his soldiers to become first Emperor of Song dynasty. His Day Master is weak yin fire but is surrounded by yang wood and yang metal. This configuration is called "Yang metal cuts the Yang wood to stimulate the yin fire.” Yang wood is like a tree, so it needs an axe to chop it into smaller pieces in order to make the fire burning bright.

There is a famous general in the Song Dynasty whose Four Pillars is also worth mentioning. He is a national hero General Yue Fei who defends the country at the border against invasion from barbarians from the North. He is a very loyal military commander with "Yang Edge" kind of Four Pillars. 
Yue Fei 1103

$\begin{array}{lccc}\text { Hour } & \text { Day } & \text { Month } & \text { Year } \\ 己 & \text { 甲 } & \text { 乙 } & \text { 癸 } \\ \text { Earth } & \text { Wood } & \text { Wood } & \text { Water } \\ \text { 巳 } & \text { 子 } & \text { 卯 } & \text { 未 } \\ \text { Fire } & \text { Water } & \text { Wood } & \text { Earth }\end{array}$

$\begin{array}{lcccc}\text { 己 } & \text { 庚 } & \text { 辛 } & \text { 壬 } & \text { 癸 } \\ \text { Earth } & \text { Metal } & \text { Metal } & \text { Water } & \text { Water } \\ \text { 西 } & \text { 戊 } & \text { 亥 } & \text { 子 } & \text { 丑 } \\ \text { Metal } & \text { Earth } & \text { Water } & \text { Water } & \text { Earth }\end{array}$

He is yang wood born in the strong wood month of Rabbit. Hence, he is "Yang Edge" in charge of thousands of soldiers. However, being "Yang Edge," the most dangerous time will be clashed between the year and the "Yang Edge" in the month. This happened in 1141, the year of Metal Rooster which is in total clash against his month of Wood Rabbit. Such clash stirs up his enemies to plot against him. In this year, people jealous of him informed the King that Yue Fei was going to betray the country. The King summoned General Yue Fei to return to the capital and executed him.

Moving on to the Ming Dynasty (1328-1644), there is another interesting Four Pillars chart which belongs to the First Emperor of the Ming Dynasty (1328-1644). The following is his Four Pillars chart.

Ming Tai Zu Hongwu Emperor 1328 21/10

$\begin{array}{lccc}\text { Hour } & \text { Day } & \text { Month } & \text { Year } \\ \text { 丁 } & \text { 丁 } & \text { 壬 } & \text { 戊 } \\ \text { Fire } & \text { Fire } & \text { Water } & \text { Earth } \\ \text { 未 } & \text { 丑 } & \text { 戊 } & \text { 辰 } \\ \text { Earth } & \text { Earth } & \text { Earth } & \text { Earth }\end{array}$

$\begin{array}{lccccccc}75 & 65 & 55 & 45 & 35 & 25 & 15 & 5 \\ \text { 庚 } & \text { 己 } & \text { 戊 } & \text { 丁 } & \text { 丙 } & \text { 乙 } & \text { 甲 } & \text { 癸 } \\ \text { Metal } & \text { Earth } & \text { Earth } & \text { Fire } & \text { Fire } & \text { Wood } & \text { Wood Water } \\ \text { 午 } & \text { 巳 } & \text { 辰 } & \text { 卯 } & \text { 寅 } & \text { 丑 } & \text { 子 亥 } \\ \text { Fire } & \text { Fire } & \text { Earth } & \text { Wood } & \text { Wood } & \text { Earth } & \text { Water Water }\end{array}$

He is considered as extremely weak yin fire as there is no support of wood in his chart. His Earthly Branches are all earth elements, Dragon, Dog, Ox, and Goat. These earth elements are storage and graves of elements. People with such storages usually possess hidden treasure, and have spiritual tendency and variety of interests. Indeed, Emperor Tai Zu was a monk before he got involved in politics. Also the plenty earth elements are his intelligence elements. Hence he is considered as extremely weak fire "follow the children" or "follow intelligence." Such person usually is very smart with high intelligence and a person with all four earth storages is very unique and unusual.

By Qing Dynasty—the last Imperial Dynasty from 1644 to 1912, Four Pillars of Destiny is already very popular and well developed. Every Emperor's Four Pillars are well recorded and analyzed. And there are quite a few famous Emperors with unique Four Pillars. The most interesting is the Four Pillars of Emperor Qianlong 
who is famous for being a romantic King who ruled China as Emperor for 63 years.

Emperor Qianlong 25/9/1711

$\begin{array}{lccc}\text { Hour } & \text { Day } & \text { Month } & \text { Year } \\ \text { 丙 } & \text { 庚 } & \text { 丁 } & \text { 辛 } \\ \text { Fire } & \text { Metal } & \text { Fire } & \text { Metal } \\ \text { 子 } & \text { 午 } & \text { 西 } & \text { 卯 } \\ \text { Water } & \text { Fire } & \text { Metal } & \text { Wood }\end{array}$

$\begin{array}{lllllllll}86 & 76 & 66 & 56 & 46 & 36 & 26 & 16 & 6\end{array}$

戊己庚辛壬癸甲 乙丙

Earth Earth Metal Metal Water Water Wood Wood Fire

子丑寅卯辰已午来申

Water Earth Wood Wood Earth Fire Fire Earth Metal

He is strong yang metal person born in September, the rooster month, which is also "Yang Edge." The unique feature of his Four Pillars is that he possesses all four "Peach Blossom"-Rabbit, Rooster, Horse, and Rat. "Peach Blossom" and "Flower of Romance" are stars of charm and attraction towards the opposite sex. Indeed he is famous for being the romantic king who liked to dress in plain clothes and went around the capital looking for pretty girl friends. He also enjoyed longevity and died at old age of 88.

The second most famous woman in Chinese history is Empress Dowager Cixi who dominated politics at the end of Qing Dynasty from 1861 to 1908.

Empress Dowager Cixi 29/11/1853

Hour Day Month Year

丙 乙 丁 乙

Fire Wood Fire Wood

子丑亥末

Water Earth Water Earth

$\begin{array}{llllllll}73 & 63 & 53 & 43 & 33 & 23 & 13 & 3 \\ \text { 乙 } & \text { 甲 } & \text { 発 } & \text { 千 } & \text { 辛 } & \text { 庚 } & \text { 己 } & \text { 戊 }\end{array}$

Wood Wood Water Water Metal Metal Earth Earth

未午已辰卯寅丑子

Earth Fire Fire Earth Wood Wood Earth Water

She has Yin wood day master and her Four Pillars is considered as "Noble yin wood born in Rat Hour." For Yin wood people, hour of rat is fire rat, whereas fire is intelligence, and rat is resources and nobleman. So yin wood day master born in rat hour which possesses such good quality of nobleman and resourceful intelligence.

In 1911, the Chinese revolution led by Dr. Sun Yat Sen successfully overthrew the Qing Dynasty and he became the first President of the Republic of China. Dr. Sun Yat Sen was born on a Yin Fire Rooster day; his Four Pillars is as below.

Dr. Sun Yat Sen 12/11/1866

Hour Day Month Year 


\begin{tabular}{llllllll} 
壬 & 丁 & 丁 & \multicolumn{1}{l}{ 乙 } & & & \\
Water & Fire & Fire & Wood & & & \\
寅 & 西 & 亥 & 丑 & & & \\
Wood & Metal & Water & Earth & & & \\
& & & & & & \\
65 & 55 & 45 & 35 & 25 & 15 & 5 & \\
庚 & 辛 & 壬 & 癸 & 甲 & 乙 & 丙 & \\
Metal & Metal & Water & Water & Wood & Wood & Fire \\
辰 & 巳 & 午 & 未 & 申 & 西 & 戊 \\
Earth & Fire & Fire & Earth & Metal & Metal & Earth
\end{tabular}

He has yin fire rooster day pillar and the rooster is Academic star as well as nobleman for Yin fire. Born in winter, his fire is weak and needs support of wood. Hence, he suffered from liver cancer (wood), and died at age 59 in 1925, when the Ox year joined up with his rooster day and snake luck to create powerful metal to kill his wood.

In 1949, the modern People's Republic of China was born under Chairman Mao, who, like Dr. Sun Yat Sen, was also born with yin fire rooster day pillar with academic star and nobleman. He is also weak yin fire born in winter but he gained strong support of yang wood from both month pillar and hour pillar. Such yang wood support symbolized the strong back up from his subordinates which was also a contributing factor for his successes.

Chairman Mao 26/12/1893

$\begin{array}{llllllllll}\text { Hour } & \text { Day } & \text { Month } & \text { Year } & & & & \\ \text { 甲 } & \text { 丁 } & \text { 甲 } & \text { 癸 } & & & & \\ \text { Wood } & \text { Fire } & \text { Wood Water } & & & & \\ \text { 辰 } & \text { 西 } & \text { 子 } & \text { 巳 } & & & & & \\ \text { Earth } & \text { Metal } & \text { Water Fire } & & & & & \\ 78 & 68 & 58 & 48 & 38 & 28 & 18 & 8 & \\ \text { 丙 } & \text { 丁 } & \text { 戊 } & \text { 己 } & \text { 庚 } & \text { 辛 } & \text { 壬 } & \text { 癸 } & \\ \text { Fire } & \text { Fire } & \text { Earth } & \text { Earth } & \text { Metal } & \text { Metal } & \text { Water } & \text { Water } \\ \text { 辰 } & \text { 巳 } & \text { 午 } & \text { 未 } & \text { 申 } & \text { 西 } & \text { 戊 } & \text { 亥 } \\ \text { Earth } & \text { Fire } & \text { Fire } & \text { Earth } & \text { Metal } & \text { Metal } & \text { Earth } & \text { Water }\end{array}$

When going through the above interesting Four Pillars of famous emperors and generals, there is an interesting phenomenon that most of the great Emperors in Chinese history were born either on a Yang earth day or yin fire day. Such day masters are very common. As we have seen from the above examples, the 3 Tang Emperors were all yang earth person. And the first emperor of Song Dynasty, Ming Dynasty, President Dr. Sun Yat Sen, Chairman Mao, and even the present Chairman Xi Jinping are all born on yin fire day. Even more amazing is that most of them were born on Yin fire Rooster day with academic star and nobleman.

The occurrence of yang earth and yin fire in Chinese history is too frequent to be played down as co-incidence. Then what is the logic behind this interesting phenomenon? There is so much mystery in the theory of 5 elements that we cannot claim we can always find a logical explanation. I can only say perhaps China is the Central Kingdom, and in the 5 elements theory, center is earth element, and that fire is the mother of earth. 


\section{Works Cited}

Raymond, Lo. Four Pillars of Destiny for Healthy Life. Hong Kong: Fung Shui Lo, 2005.

---. The Old Secret-Essential Four Pillars of Destiny. Hong Kong: Fung Shui Lo, 2012.

---. Curiosity—Solve Mysteries with Four Pillars of Destiny. Hong Kong: Fung Shui Lo, 2015. 